\title{
The US Refugee Resettlement Program - A Return to First Principles: How Refugees Help to Define, Strengthen, and Revitalize the United States
}

\section{Donald Kerwin}

"The bosom of America is open to receive not only the Opulent and respectable Stranger, but the oppressed and persecuted of all Nations and Religions, whom we shall welcome to a participation of all our rights and privileges, if by decency and propriety of conduct they appear to merit the enjoyment."

George Washington, December 2, 1783

"In this world of globalization we have fallen into a globalization of indifference. We are accustomed to the suffering of others, it doesn't concern us, it's none of our business."

Pope Francis, Homily at Lampedusa, July 8, 2013

\section{Executive Summary}

The US refugee resettlement program should be a source of immense national pride. The program has saved countless lives, put millions of impoverished persons on a path to work, self-sufficiency, and integration, and advanced US standing in the world. Its beneficiaries have included US leaders in science, medicine, business, the law, government, education, and the arts, as well as countless others who have strengthened the nation's social fabric through their work, family, faith, and community commitments. Refugees embody the ideals of freedom, endurance, and self-sacrifice, and their presence closes the gap between US ideals and its practices. For these reasons, the US Refugee Admissions Program (USRAP) has enjoyed strong, bipartisan support for nearly 40 years.

Yet the current administration has taken aim at this program as part of a broader attack on legal immigration programs. It has treated refugees as a burden and a potential threat to our nation, rather than as a source of strength, renewal, and inspiration. In September 2017, it set an extremely low refugee admissions ceiling $(45,000)$ for 2018 , which it had no intention of meeting: the United States is on pace to resettle less than one-half of that number. It has also tightened special clearance procedures for refugees from mostly Muslim-majority states so that virtually none can enter; cynically slow-walked the interview, screening, and admissions processes; and decimated the community-based resettlement infrastructure built up over many decades (Miliband 2018). At a time of record levels of forced displacement in the world, the United States should model solidarity with refugees and exercise leadership in global refugee protection efforts (Francis 2018a, 102). Instead, the administration has put the United States on pace to resettle the lowest number of refugees in USRAP's 38-year history, with possible further cuts in fiscal year (FY) 2019. 
This report describes the myriad ways in which this program serves US interests and values. The program:

- saves the lives of the world's most vulnerable persons;

- continues "America's tradition as a land that welcomes peoples from other countries" and shares the "responsibility of welcoming and resettling those who flee oppression" (Reagan 1981);

- promotes a "stable and moral world" (Helton 2002, 120);

- reduces spontaneous, unregulated arrivals and encourages developing nations to remain engaged in refugee protection (Gammeltoft-Hansen and Tan 2017, 42-43); and

- promotes cooperation from individuals, communities, and nations that are central to US military and counter-terrorism strategies. ${ }^{1}$

In that vein, the report describes the achievements, contributions, and integration outcomes of 1.1 million refugees who arrived in the United States between 1987 and 2016. It finds that:

- the median household income of these refugees is $\$ 43,000 ;{ }^{2}$

- 35 percent of refugee households have mortgages;

- 63 percent of refugees have US-born children;

- 40 percent are married to US citizens; and

- 67 percent have naturalized.

Comparing the 1.1 million refugees who arrived between 1987 and 2016 with non-refugees, ${ }^{3}$ the foreign born, and the total US population, the report finds:

- Refugees' labor force participation (68 percent) and employment rates (64 percent) exceed those of the total US population (63 and 60 percent respectively). ${ }^{4}$

- Large numbers of refugees (10 percent) are self-employed and, in this and other ways, job creators, compared to 9 percent for the total US population.

- Refugees' median personal income $(\$ 20,000)$ equals that of non-refugees and exceeds the income of the foreign born overall $(\$ 18,700)$.

1 Brief for Retired Generals and Admirals of the US Armed Forces in Support of Respondents at 19-21, Trump v. Hawaii, No. 1 7-965 (Mar. 30, 2018).

2 This is less than the median household income of the non-refugee population $(\$ 45,000)$, the foreign born $(\$ 56,000)$, and the total US population $(\$ 52,800)$. However, most refugees enter the United States without income, assets, or English language proficiency, and they advance dramatically over time. This report shows, for example, that the median personal income of refugees who arrived between 1987 and 1996 actually exceeds that of the total US population.

3 The Center for Migration Studies identified non-refugees by removing persons selected as refugees from the population of all foreign born that entered after 1986, by single year of entry. In each year of entry, it then randomly selected the same number as the number of refugees.

4 The labor force participation rate refers to the percentage of persons age 16 or over who are employed or seeking 2 
- Refugees are more likely to be skilled workers (38 percent) than non-refugees (33 percent) or the foreign born (35 percent).

- Refugees are less likely to work in the jobs that new immigrants fill at high rates, such as construction, restaurants and food service, landscaping, services to buildings and dwellings, crop production, and private households.

- Refugees use food stamps and Medicaid at higher rates than non-refugees, the foreign born, and the total US population. However, their public benefit usage significantly declines over time and their integration, well-being, and US family ties increase.

Comparing refugee characteristics by time present in the United States - from the most recent arrivals (2007 to 2016), to arrivals between 1997 to 2006, to those with the longest tenure (1987 to 1996$)$ - the report finds:

- Refugees with the longest residence have integrated more fully than recent arrivals, as measured by households with mortgages (41 to 19 percent); English language proficiency (75 to 55 percent); naturalization rates ( 89 to 24 percent); college education (66 to 32 percent); labor force participation (68 to 61 percent); and employment (66 to 55 percent) and selfemployment (14 to 4 percent).

- Refugees who arrived from 1997 to 2006 have higher labor force participation and employment rates than refugees who arrived from 1987 to $1996 .{ }^{5}$

- Refugees who arrived between 1987 and 1996 exceed the total US population, which consists mostly of the native born, in median personal income $(\$ 28,000$ to $\$ 23,000)$, homeownership (41 to 37 percent with a mortgage), percent above the poverty line (86 to 84 percent), access to a computer and the internet ( 82 to 75 percent), and health insurance (93 to 91 percent).

Comparing nationals - in 2000 and again in 2016 - from states formerly in the Soviet Union, who entered from 1987 to 1999, the report finds that:

- median household income increased, from $\$ 31,000$ to $\$ 53,000$;

- median personal income nearly tripled, from $\$ 10,700$ to $\$ 31,000$;

- the percent of households with a mortgage increased from 30 to 40 percent;

- public benefit usage fell;

- English language proficiency rose;

- the percent with a college degree or some college increased (68 to 80 percent);

- $\quad$ naturalization rates nearly doubled, from 47 to 89 percent;

- marriage to US citizens rose from 33 to 51 percent; and

5 The higher labor force participation and employment rates of refugees who arrived from 1997 to 2006 can likely be attributed to the older age of those who arrived from 1987 to 1996 (20 percent age 65 or over). Many of those who arrived in the 1987 to 1996 period had likely retired by 2016 . 
- labor force participation rate (59 to 69 percent), employment (57 to 66 percent), selfemployment (11 to 15 percent), and the rate of skilled workers (33 to 38 percent) all grew.

The report also finds that refugees bring linguistic diversity to the United States and, in this and other ways, increase the nation's economic competitiveness and security.

In short, refugees become US citizens, homeowners, English speakers, workers, business owners, college educated, insured, and computer literate at high rates. These findings cover a large population of refugees comprised of all nationalities, not just particularly successful national groups.

Section I of the report describes the nation's historic commitment to refugees and critiques the administration's rationale for dismantling the resettlement program. Section II sets forth the Center for Migration Studies' (CMS) methodology for selecting the refugee data used in this report. Section III discusses the resettlement, national origins, and years of arrival of the refugees in CMS's sample. Section IV details the report's main findings on the achievements, contributions, and integration of refugees over time. It compares the characteristics of refugees, non-refugees, the foreign born, and the total US population; and examines the progress of refugees - measured in 2000 and 2016 - that arrived from the former Soviet Union between 1987 and 1999. This section also references the growing literature on the US refugee program and on the economic and fiscal impacts of refugees. Section $V$ discusses the important role of voluntary agencies in the resettlement process, focusing on the work of Catholic agencies in building community support for refugees and promoting their entrepreneurial initiatives. Section VI identifies the national interests served by the refugee program, recommends ways to address several of the program's longstanding challenges, and urges the president, Congress, Americans with refugee roots, and other stakeholders to work to strengthen and expand the program.

\section{Introduction}

The US refugee program constitutes one of the most successful humanitarian programs in US history. Since passage of the Refugee Act of 1980, ${ }^{6}$ which established the current US Refugee Admissions Program (USRAP), the United States has resettled more than 3 million refugees (Table A). However, the US tradition of providing haven to the oppressed and persecuted stretches back far longer. In the post-World War II era, in particular, Congress passed several pieces of legislation to admit large-scale refugee populations (DHS 2003, 49-50). The Displaced Persons Act of 1948 (amended in 1950), ${ }^{7}$ for example, led to the admission of 400,000 refugees and the Refugee Relief Act of 1953 to another 200,000, beyond then existing nationality quotas. ${ }^{8}$ The United States also "paroled" - admitted on a temporary basis primarily for humanitarian reasons - more than 30,000 Hungarian refugees following the Soviet-suppressed Hungarian revolution of 1956,

\footnotetext{
6 Refugee Act of 1980, Pub. L. No. 96-212, 94 Stat. 102 (1980).

7 Pub. L. No. 80-77, 62 Stat. 1009 (1948).

8 Pub. L. No. 83-203, 67 Stat. 400 (1953). Additional refugee protection legislation from this era included the Act of September 11, 1957, which allowed the admission of "refugee escapees" from communist-dominated nations and refugees from the Middle East who had suffered persecution or feared persecution on account of "race, religion, or political opinion"; the Fair Share Refugee Act of 1960, which provided for the admission of World War II refugees and displaced persons and vested the Attorney General with authority to grant parole to "refugee-escapees"; and the Immigration and Nationality Act Amendments of 1965, which established a "conditional entry" category for refugees (Select Commission on Immigration and Refugee Policy1981, 202 and 211).
} 
175,000 Indochinese refugees following the fall of Saigon in 1975, and 640,000 Cubans following the communist revolution through May 1979 (USCIR 1997, 215; Kerwin 2010, 4-5). ${ }^{9}$

This tradition should be a source of immense national pride. The US refugee program has advanced the nation's standing in the world, saved countless lives, and put millions of impoverished refugees on a path to work, self-sufficiency, and integration. It has admitted future leaders in science, health care, business, the law, government, education, and the arts, ${ }^{10}$ as well as countless new Americans that have strengthened the nation's social fabric through their work, family, faith, and community commitments. Refugees embody and serve as living reminders of the ideals of freedom, endurance, hard work, and self-sacrifice. Their presence closes the gap between the nation's ideals and practices.

"Being a refugee wasn't a choice and growing up in the refugee camp I felt like a bird forced to remain in a cage and not able to fly. The US refugee program gave me hope for a better future. Without it, I wouldn't be here and able to pursue higher education. I am thankful for the opportunity to be resettled in the United States. Despite the many challenges, the US Refugee Program opens the door and gives people like me a chance to live, dream, and achieve goals and a better future. There are many refugee children, women, and men who have to live in fear without many resources. The US Refugee Program makes a positive impact for many others including myself. I hope the program can continue to open the door to those in need and give them a chance."

- Paw Say Ku, Heartland Care Alliance, Youth Substance Abuse Prevention Program Coordinator

Yet the current administration has worked to dismantle this program, as part of a broader attack on legal immigration programs like Temporary Protected Status (TPS), Deferred Action for Childhood Arrivals (DACA), and the Central American Minors (CAM) program (Kerwin 2017). Most recently, the administration has sought to deter asylum seekers from attempting to access US territory, by formalizing its practice of removing children from their parents' custody at the US-Mexico border and criminally prosecuting the parents, mostly for illegal entry (Gamboa and Silva 2018).

In September 2017, the administration set an extremely low refugee admissions ceiling $(45,000)$ for FY 2018, but the United States will likely admit less than one-half of that number. It tightened the special clearance procedures for refugees from mostly Muslim-majority states to the point that virtually none can enter; has cynically slow-walked the refugee interview, screening, and admissions processes; and has decimated the community-based resettlement infrastructure built up over many decades (Miliband 2018).

9 Congress has also regularly passed legislation to extend lawful permanent resident (LPR) status to "parolees" and other refugee-like populations admitted on a temporary basis (USCIR 1997, 215, Kerwin 2010 5-6).

10 A short list of prominent US refugees includes Madeleine Albright, Sergey Brin, Marc Chagall, Albert Einstein, Enrico Fermi, Andrew Grove, Henry Kissinger, George Soros, and Elie Wiesel. 
The United States admitted more than 3 million refugees between FY 1980 and FY 2018 (year to date) (Table A). However, at a time of record levels of forced displacement in the world, ${ }^{11}$ it is on pace to resettle the lowest number of refugees in USRAP's 38-year history (Table A), with further cuts expected in FY 2019.

Table A. Refugee Arrivals (FY 1980-May 11, 2018)

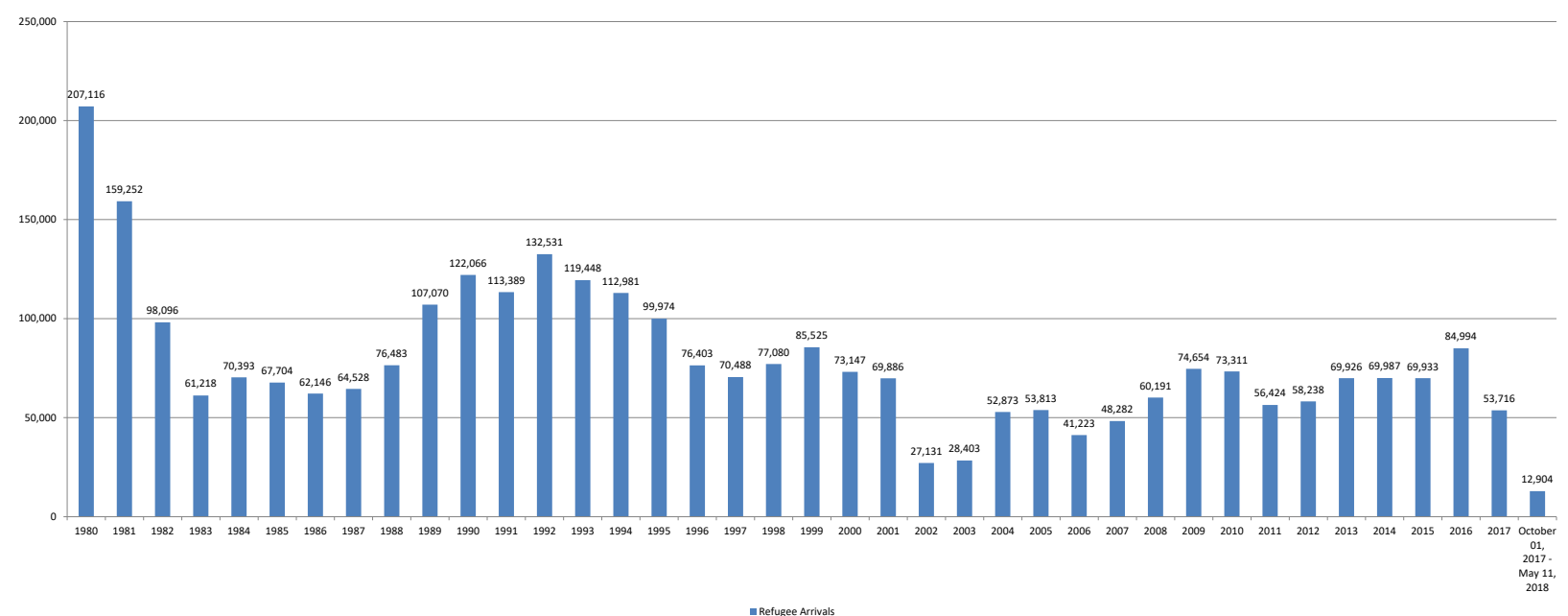

Sources: DHS (2014), Bruno (2017), and DOS/PRM (2018a,b).

This alarming turn of events has been buttressed by meretricious attacks on the program that: (1) conflate refugees with terrorists and criminals; (2) aver the United States lacks the "absorptive capacity" to admit more refugees; and (3) question the willingness and ability of refugees to integrate in the United States. None of these claims can be sustained.

First, refugees do not threaten national security or public safety. To the contrary, they advance the nation's security by contributing to its economic well-being, diversity, and military strength (Kerwin 2016, 91-93). Moreover, every act of refugee protection - from addressing refugeeproducing conditions to pursuing permanent solutions for refugees - promotes security (ibid.). Criminals and terrorists occasionally attempt to impersonate refugees, but refugees undergo the most intensive screening of any group of travelers to the United States (DOS/PRM 2018c), and of perhaps any refugee population in the world. ${ }^{12}$ In addition, resettled refugees belong to groups not associated with terrorist or criminal enterprises and that particularly need protection - the elderly, the ill, women with young children, imperiled religious minorities, and persons who worked for the US military in Iraq and Afghanistan (ibid., 89, 97-98).

Second, the notion that the United States cannot absorb more refugees mischaracterizes the relationship between refugees and their new communities. Refugees need assistance when they arrive, but they are not passive objects of absorption. The US resettlement program promotes the economic self-sufficiency of refugees through early employment, a goal that it achieves at

11 The United Nations High Commissioner for Refugees reports that by the end of 2016, 65.6 million persons had been forcibly displaced by persecution, conflict, violence, or human rights violations, including 22.5 million refugees, 40.3 million internally displaced persons, 10 million stateless persons, and 2.8 million with pending asylum applications (UNHCR 2017). According to the International Disaster Monitoring Centre and the Norwegian Refugee Council, sudden-onset natural hazards displaced an additional 24.2 million persons in 2016 and an average of 25.3 million persons per year since 2008 (IDMC and NRC 2017, 31).

12 As a result, the chance of dying in a US terrorist attack by a refugee is negligible (Nowrasteh 2016). 
remarkably high rates. ${ }^{13}$ Moreover, refugees contribute significantly to their new communities. For example, they have revitalized economically depressed communities like North Hill in Akron, Ohio; Bevo Mill in St. Louis; parts of Buffalo and Utica, New York; and Cleveland, Ohio. ${ }^{14}$ In addition, over time refugees pay more in taxes than they receive in public benefits. ${ }^{15}$

Large-scale, chaotic migration poses a challenge to refugee integration. However, USRAP is a case study in safe, orderly, and controlled migration, and the pool of refugees eligible for resettlement is modest. The United Nations High Commissioner for Refugees (UNHCR) refers only a fraction of one percent of the world's refugees for resettlement each year, making those resettled to third countries a highly select and well-screened group (UNHCR 2017, 27).

The United States can accommodate more refugees than it does. By way of comparison, Turkey, Lebanon, Jordan, Iraq, and Egypt - with a combined gross domestic product (GDP) of less than \$1.5 trillion in 2016 (World Bank 2018) - host more than 5.6 million Syrian refugees, and large populations from other nations as well (UNHCR 2018a). Uganda, Sudan, Kenya, Ethiopia, and the Democratic Republic of the Congo - with a combined GDP of \$299 billion in 2016 (World Bank 2018) - host more than 2.4 million South Sudanese refugees (UNHCR 2018b). The United States - with a GDP of \$18.6 trillion (World Bank 2018) - resettled 44 Syrian refugees and 11 South Sudanese refugees during the first seven months of FY 2018 (DOS/PRM 2018). As for lack of community support, local resettlement agencies report that they are overwhelmed by the outpouring of volunteers and offers of cash and in-kind contributions to support this life-saving program. In addition, interest in the private sponsorship of refugees has been growing in recent years (Kantor and Einhorn 2016).

13 In FY 2015, 67 percent of the 29,765 refugee participants in the US Department of Health and Human Services, Office of Refugee Resettlement (HHS/ORR) Matching Grant public-private partnership program achieved economic self-sufficiency within 120 days and 82 percent within 180 days (HHS/ORR 2017, 20). HHS/ORR defines economic selfsufficiency as "earning a total family income at a level that enables the case unit to support itself without receipt of a cash assistance grant," meaning in practice "earnings that exceed the income eligibility level for receipt of a TANF [Temporary Assistance for Needy Families] cash assistance grant in the state and the ability to cover the family living expenses" (ibid.).

14 Refugees helped to "create and preserve" an estimated 1,156 manufacturing jobs in Akron (NAE 2016). The Cleveland area's 7,649 refugees supported 1,220 local jobs in 2016, contributed \$2.7 million in taxes to the State of Ohio and \$1.8 million to county and city governments (Chmura Economics \& Analytics 2017). In Franklin Country, Ohio, refugees own businesses at twice the rate of the overall population (13.6 versus 6.5 percent): the 873 refugeeowned businesses in the Columbus metropolitan area generated $\$ 605.7$ million and supported 7,851 jobs in 2015 (Community Research Partners 2015). Refugee service agencies also contribute economically to local communities. In the Cleveland area, refugee organizations spent \$17.7 million in 2016 and employed 340 people (Chmura Economics \& Analytics 2017). In Georgia, refugee agencies contributed an estimated \$2.7 million to the state's economy in FY 2015 (CRSA 2016).

15 Across the United States, 2.3 million refugees earned $\$ 77.2$ billion in household income in 2015 and contributed $\$ 20.9$ billion in taxes, including \$14.5 billion to the federal government and \$6.4 billion to states and localities (NAE 2017). After eight years, refugees begin to pay more in taxes than they receive in public benefits (Evans and Fitzgerald 2017). An HHS study on the fiscal costs of refugees between FY 2005 and FY 2014 found that refugees contributed $\$ 63$ billion in taxes, including $\$ 40.9$ billion in federal taxes and $\$ 22$ billion in state and local taxes (HHS 2017). Moreover, each refugee pays an average of $\$ 4,600$ more in taxes than they receive in benefits. The Trump administration rejected the HHS report, reportedly because it speaks to the contributions of refugees and not exclusively about the benefits they use. 


\section{Aya Alkhdair}

After fleeing Sudan for Egypt, Aya Alkhdair and her family were settled in Westbrook, Maine in March 2015. Since arriving in the United States, Aya has participated in several initiatives that promote refugee youth involvement in humanitarian work, and she has assisted refugee populations in their cultural adjustments. She is a certified Medical Interpreter (Arabic-English) and has worked closely with the refugee and immigrant communities in Maine. In October 2017, Aya co-founded a nonprofit organization with another former refugee that provides personal support specialists to people approved for in-home patient care. Aya and her co-founder hope this venture will also allow them to employ and help to integrate migrants and other former refugees into US society. Recently, after only 2.5 years of study, Aya graduated from the University of Southern Maine with bachelor's degrees in Human Biology and Biochemistry. She plans to become a physician specializing in infectious disease and is currently studying for the MCAT and applying to medical schools.

Aya attributes her achievements to the US refugee program, which allowed her to accomplish so much in such a short amount of time. "It is really difficult to make things happen when you are scared for your life and scared you'll be hurt physically and emotionally," she says. "When I was a refugee, I could not do the things I can do now - I couldn't leave my house, go to school, or volunteer. Being here - safe in the United States - is one of the greatest blessings in my life. There are so many refugees that have potential to succeed but are trapped in unsafe situations and by limited resources. But when they are provided safety and opportunities, refugees are given a second life and are able to shine."

Third, there is nothing alien about refugees to the American experience or to a nation open to the "oppressed and persecuted of all nations and religions." ${ }^{16}$ Refugees strongly embrace defining US values like freedom and the rule of law, having fled situations characterized by their absence. As discussed in this report, they also strengthen the social fabric and make myriad contributions to the success of their new nation.

\section{Methodology for Refugee Selection}

This report examines 1.1 million of the 2.3 million refugees admitted to the United States from 1987 to 2016 . This large sample, containing the full range of demographic data collected in the American Community Survey (ACS), provides a detailed portrait of the refugee population that arrived over this 30-year period.

The 1.1 million refugees were enumerated in the 2016 ACS, which is conducted annually by the US Census Bureau. CMS chose 1987 as its starting point for three reasons: (1) in 1987, large numbers of refugees were just beginning to arrive from the Soviet Union; (2) it sought to identify respondents in the 2016 ACS that had arrived as refugees and many refugees that arrived before 
1987 had died or retired by 2016; and (3) annual data on refugee and immigrant arrivals ${ }^{17}$ from the US Department of Homeland Security (DHS) were available for every country in the 1987 to 2016 period.

CMS used the following methodology to identify respondents in the 2016 ACS. First, it compiled DHS statistics on refugee arrivals by country of birth and year of entry. ${ }^{18} \mathrm{Next}$, it compiled DHS data for newly arriving lawful permanent residents (LPRs) by country of birth and year of entry. Then, it identified country-by-year cells in which refugee arrivals were at least twice ${ }^{19}$ the number of new LPR arrivals. ${ }^{20}$ It used the percentages of refugees in those cells to select refugees randomly from corresponding cells in the 2016 ACS data.

Refugees who arrived from Bosnia in 1997 and appeared in the 2016 ACS illustrate CMS's procedures. According to DHS statistics compiled in 1997, 21,357 refugees and 132 LPRs arrived from Bosnia. Thus, 99.4 percent of the total arrivals from Bosnia in 1997 were refugees. The 2016 ACS counted 15,857 Bosnians that arrived in 1997. Multiplying the ACS estimate of 15,857 by .994 yields 15,762, which is the estimated number of refugees from Bosnia counted in the 2016 ACS. Random selection from the ACS microdata was used to select 15,762 of the 15,857 respondents from Bosnia, producing detailed demographic data for this study.

To compile non-refugees, CMS began with all foreign born that entered after 1986, by single year of entry. It then removed those that had been selected as refugees. Finally, in each year of entry, it randomly selected the same number as the number of refugees. It derived the non-refugee population in order to have a comparable population (to refugees), controlled for length of stay in the United States.

Appendix A summarizes the selection of refugee data used in this report. Slightly fewer than half (1.1 million out of 2.3 million) of all refugees admitted in 1987 to 2016 are included in this study.

\section{Refugee Resettlement, Origin, and Arrival Data}

The composition of refugees to the United States changes over time. As illustrated by CMS's sample, large numbers arrived from the former Soviet Union and Southeast Asia from 1987 to 1999; from Bosnia in the late 1990s; and from Middle Eastern, African, and South and Southeast Asian countries in subsequent decades (Table B).

As befits a national program, refugees are widely dispersed throughout the country. California, New York, Minnesota, Washington, Texas and Florida host the largest numbers of refugees (Table E). However, Minnesota, Nebraska, Washington, New York, and lowa host the most refugees per 1,000 total population (Table C).

17 Source comes from annual statistics, by country, provided by the US Department of Homeland Security (DHS). Note that the LPR numbers used to prepare this report refer to newly arriving LPRs and not to the total number that received LPR status in a year. The latter would include immigrants that arrived in earlier years but adjusted to permanent resident status during the year.

18 See Table 14, annual DHS Yearbook of Immigration Statistics.

19 Using a minimum ratio of 2 to 1 (refugees to LPR arrivals) yielded 2016 ACS data in which roughly 90 percent of the $1,088,000$ were refugees. The 90 percent figure is based on the probability of selection within each cell.

20 Far more Cubans entered as refugees over the years examined in this report than are counted in CMS's data. To be counted, refugees had to outnumber new LPR arrivals by a 2:1 ratio. In some years, there were roughly as many newly arriving Cuban LPRs as refugees. Thus, most of the Cuban refugees that arrived during these years are not included in CMS's refugee data. 
Table B. Refugees in CMS Sample, by Country of Origin and Period of Entry: 2016

Estimates less than 500 not shown.

\begin{tabular}{|c|c|c|c|c|c|}
\hline Country of origin & $\begin{array}{r}\text { All periods of } \\
\text { entry }\end{array}$ & $\begin{array}{r}\text { Entered } 1987 \\
\text { to } 1991\end{array}$ & $\begin{array}{r}\text { Entered } 1992 \\
\text { to } 1999\end{array}$ & $\begin{array}{r}\text { Entered } 2000 \\
\text { to } 2007\end{array}$ & $\begin{array}{r}\text { Entered } 2008 \\
\text { to } 2015\end{array}$ \\
\hline Total & $1,088,600$ & 236,900 & 403,000 & 142,000 & 306,700 \\
\hline Cuba & 18,600 & - & - & 18,600 & - \\
\hline Albania & 3,500 & 1,500 & 2,000 & - & - \\
\hline Bulgaria & 2,700 & 2,700 & - & - & - \\
\hline Hungary & 2,900 & 2,900 & - & - & - \\
\hline Romania & 10,000 & 10,000 & - & - & - \\
\hline Croatia & 4,300 & - & 2,700 & 1,600 & - \\
\hline Serbia & 2,800 & - & 2,800 & - & - \\
\hline Bosnia & 91,000 & - & 70,900 & 20,000 & - \\
\hline Latvia & 2,700 & 1,300 & 1,300 & - & - \\
\hline Russia & 97,700 & 44,000 & 53,800 & - & - \\
\hline Byelorussia & 27,100 & 9,900 & 17,200 & - & - \\
\hline Moldavia & 17,600 & 5,000 & 8,900 & 3,800 & - \\
\hline Ukraine & 139,500 & 42,900 & 96,600 & - & - \\
\hline Armenia & 20,800 & 18,200 & 2,600 & - & - \\
\hline Azerbaijan & 7,200 & 2,000 & 5,200 & - & - \\
\hline Georgia & 2,200 & 1,500 & 700 & - & - \\
\hline Kazakhstan & 6,300 & 2,900 & 3,300 & - & - \\
\hline Uzbekistan & 17,300 & 3,300 & 14,000 & - & - \\
\hline USSR, ns & 9,600 & - & 7,300 & 2,300 & - \\
\hline Cambodia & 8,800 & 8,800 & - & - & - \\
\hline Laos & 51,800 & 33,600 & 13,200 & 5,000 & - \\
\hline Vietnam & 92,600 & 28,500 & 64,100 & - & - \\
\hline Afghanistan & 16,400 & 7,200 & 1,900 & 7,200 & - \\
\hline Bhutan & 49,600 & - & - & - & 49,600 \\
\hline Burma & 91,000 & - & - & 10,200 & 80,800 \\
\hline Iraq & 131,100 & - & 8,800 & 4,500 & 117,800 \\
\hline Syria & 6,600 & - & - & - & 6,600 \\
\hline Sudan & 13,200 & - & 2,100 & 9,700 & 1,500 \\
\hline Liberia & 22,500 & - & 3,800 & 18,600 & - \\
\hline Sierra Leone & 2,000 & - & - & 2,000 & - \\
\hline Ethiopia & 14,900 & 10,200 & 4,700 & - & - \\
\hline Somalia & 73,900 & - & 15,000 & 31,700 & 27,100 \\
\hline Eritrea & 12,500 & - & - & 900 & 11,600 \\
\hline Congo & 17,600 & - & - & 5,900 & 11,700 \\
\hline Other countries & 400 & 400 & - & - & - \\
\hline
\end{tabular}

Source: Derived from 2016 ACS data, compiled by CMS; see text. 
Table C. Number of Refugees per 1,000 Total Population, by State of Residence in 2016

States with 10,000 or more refugees in CMS sample; ranked by refugees per 1,000 total population.

\begin{tabular}{|c|c|c|c|}
\hline State of residence & $\begin{array}{r}\text { Refugees in CMS } \\
\text { sample (thousands) }\end{array}$ & $\begin{array}{r}\text { Total US population } \\
\text { (thousands) }\end{array}$ & $\begin{array}{r}\text { Refugees per } \begin{array}{r}1,000 \text { total } \\
\text { population }\end{array}\end{array}$ \\
\hline All states & 1,089 & 323,128 & 3.4 \\
\hline Minnesota & 61 & 5,520 & 11.1 \\
\hline Nebraska & 15 & 1,907 & 8.0 \\
\hline Washington & 58 & 7,288 & 7.9 \\
\hline New York & 124 & 19,745 & 6.3 \\
\hline lowa & 18 & 3,135 & 5.7 \\
\hline California & 178 & 39,250 & 4.5 \\
\hline Massachusetts & 30 & 6,812 & 4.4 \\
\hline Michigan & 43 & 9,928 & 4.4 \\
\hline Maryland & 24 & 6,016 & 3.9 \\
\hline Kentucky & 17 & 4,437 & 3.8 \\
\hline Arizona & 24 & 6,931 & 3.5 \\
\hline Virginia & 29 & 8,412 & 3.4 \\
\hline Pennsylvania & 44 & 12,784 & 3.4 \\
\hline Oregon & 14 & 4,093 & 3.4 \\
\hline Connecticut & 12 & 3,576 & 3.4 \\
\hline New Jersey & 30 & 8,944 & 3.3 \\
\hline Missouri & 20 & 6,093 & 3.2 \\
\hline Illinois & 39 & 12,802 & 3.1 \\
\hline Ohio & 33 & 11,614 & 2.9 \\
\hline Georgia & 28 & 10,310 & 2.7 \\
\hline Wisconsin & 16 & 5,779 & 2.7 \\
\hline Indiana & 16 & 6,633 & 2.5 \\
\hline Florida & 46 & 20,612 & 2.2 \\
\hline North Carolina & 22 & 10,147 & 2.2 \\
\hline Colorado & 12 & 5,541 & 2.1 \\
\hline Texas & 57 & 27,863 & 2.1 \\
\hline Tennessee & 13 & 6,651 & 1.9 \\
\hline Other states and DC & 65 & 50,303 & 1.3 \\
\hline
\end{tabular}

Source: Column 1, data compiled by CMS, see text; column 2, 2016 ACS.

Nearly 60 percent of the refugees in CMS's sample live in just 18 metropolitan areas (Table D), led by the New York-Newark-Jersey City metropolitan area. 
Table D. Refugees in CMS Sample Residing in the Major Metro Areas

Metro areas with 10,000 or more refugees are shown.

Metro area

Refugees

Total refugees in CMS sample

$1,088,600$

Refugees in CMS sample, lived in these 18 metro areas

643,800

Percent that resided in these 18 metro areas

New York-Newark-Jersey City, NY-NJ-PA

121,800

Los Angeles-Long Beach-Anaheim, CA

Minneapolis-St. Paul-Bloomington, MN-WI

52,100

Seattle-Tacoma-Bellevue, WA

42,500

Chicago-Naperville-Elgin, IL-IN-WI

35,500

Washington-Arlington-Alexandria, DC-VA-MD-WV

33,400

San Diego-Carlsbad, CA

32,100

Detroit-Warren-Dearborn, MI

31,300

Philadelphia-Camden-Wilmington, PA-NJ-DE-MD

28,200

Dallas-Fort Worth-Arlington, TX

27,700

Atlanta-Sandy Springs-Roswell, GA

24,800

San Francisco-Oakland-Hayward, CA

24,500

Sacramento--Roseville--Arden-Arcade, CA

23,500

Miami-Fort Lauderdale-West Palm Beach, FL

22,500

Boston-Cambridge-Newton, MA-NH

21,900

Phoenix-Mesa-Scottsdale, AZ

19,600

Houston-The Woodlands-Sugar Land, TX

15,600

San Jose-Sunnyvale-Santa Clara, CA

12,900

Source: Derived from 2016 ACS data, compiled by CMS; see text.

The Department of State and resettlement agencies attempt to place refugees near family members in order to promote their "long term chance of success in the United States" (DOS/ PRM 2018c). Refugees also tend to move to communities with significant numbers of residents from their countries of origin. Not surprisingly, most Cuban refugees in CMS's 2016 sample live in Florida (Table E). Refugees in Minnesota mostly come from Somalia, Laos, and Burma. Large numbers of Iraqi and Burmese refugees have settled in Texas. Ukrainians and Somalis represent the two largest refugee populations in the State of Washington.

California and New York have the largest and most diverse refugee populations. They are also the states that have the largest concentrations of refugees from individual countries of origin (11 and 9 respectively). Florida hosts the largest number of Hungarian refugees, Indiana the most Burmese refugees, Missouri the most Bosnians, and Ohio the most Bhutanese (Table F). 
Table E. Refugees in CMS Sample, by Country of Origin, Six Top States of Residence: 2016

State estimates less than 500 not shown.

- zero or rounds to zero

\begin{tabular}{|c|c|c|c|c|c|c|c|}
\hline Country & US total & CA & NY & $\mathrm{MN}$ & WA & TX & $\mathrm{FL}$ \\
\hline Total & $1,088,600$ & 178,100 & 124,100 & 61,400 & 57,800 & 57,400 & 46,300 \\
\hline Cuba & 18,600 & - & - & - & - & - & 16,500 \\
\hline Albania & 3,500 & - & 1,000 & - & - & - & - \\
\hline Bulgaria & 2,700 & - & - & - & - & - & - \\
\hline Hungary & 2,900 & 500 & - & - & - & - & 900 \\
\hline Romania & 10,000 & 2,100 & 1,500 & - & - & - & - \\
\hline Croatia & 4,300 & - & - & - & - & 700 & - \\
\hline Serbia & 2,800 & - & - & 1,100 & - & - & - \\
\hline Bosnia & 91,000 & 5,200 & 8,200 & 2,600 & 2,800 & 3,400 & 3,400 \\
\hline Latvia & 2,700 & 600 & - & - & - & - & - \\
\hline Russia & 97,700 & 17,600 & 23,500 & 1,700 & 2,700 & 1,700 & 4,600 \\
\hline Byelorussia & 27,100 & 3,700 & 9,300 & 500 & 700 & 600 & 1,100 \\
\hline Moldavia & 17,600 & 3,200 & 4,900 & - & 2,500 & - & - \\
\hline Ukraine & 139,500 & 21,900 & 37,100 & 1,800 & 14,300 & 900 & 4,500 \\
\hline Armenia & 20,800 & 18,900 & 500 & - & - & - & - \\
\hline Azerbaijan & 7,200 & 800 & 2,000 & - & - & - & - \\
\hline Georgia & 2,200 & - & 800 & - & - & - & - \\
\hline Kazakhstan & 6,300 & - & 1,600 & - & 1,100 & - & 800 \\
\hline Uzbekistan & 17,300 & 900 & 9,800 & - & - & - & - \\
\hline USSR, ns & 9,600 & 1,600 & 1,200 & - & 700 & - & - \\
\hline Cambodia & 8,800 & 4,200 & 500 & - & - & - & - \\
\hline Laos & 51,800 & 14,100 & - & 10,900 & 2,000 & 1,600 & 1,700 \\
\hline Vietnam & 92,600 & 33,900 & 1,900 & 4,100 & 5,500 & 8,600 & 2,700 \\
\hline Afghanistan & 16,400 & 7,000 & 1,700 & - & - & - & - \\
\hline Bhutan & 49,600 & - & 1,600 & 500 & 1,900 & 3,800 & - \\
\hline Burma & 91,000 & 5,000 & 6,600 & 7,200 & 3,800 & 10,200 & 3,400 \\
\hline Iraq & 131,100 & 26,000 & 3,100 & - & 5,500 & 12,900 & 3,200 \\
\hline Syria & 6,600 & - & - & - & - & - & - \\
\hline Sudan & 13,200 & 800 & - & 1,500 & - & 700 & - \\
\hline Liberia & 22,500 & 500 & 1,100 & 4,200 & - & 2,300 & - \\
\hline Sierra Leone & 2,000 & - & - & - & - & - & - \\
\hline Ethiopia & 14,900 & 2,500 & 900 & - & 1,600 & 900 & 500 \\
\hline Somalia & 73,900 & 1,600 & 700 & 24,500 & 8,100 & 1,200 & - \\
\hline Eritrea & 12,500 & 2,700 & 600 & - & 1,900 & 700 & - \\
\hline Congo & 17,600 & 1,100 & 2,900 & - & - & 4,100 & - \\
\hline Other countries & 400 & - & - & - & - & - & - \\
\hline
\end{tabular}

Source: CMS estimates of refugees derived from 2016 ACS; see text. 
Table F. State of Residence with the Largest Number of Refugees for Each Country of Origin: 2016

\begin{tabular}{|c|c|c|}
\hline Country & $\begin{array}{l}\text { Largest number of refugees } \\
\text { in any state }\end{array}$ & $\begin{array}{l}\text { State of residence } \\
\text { of largest number }\end{array}$ \\
\hline US total & 178,100 & N/A \\
\hline Vietnam & 33,900 & California \\
\hline Iraq & 26,000 & California \\
\hline Armenia & 18,900 & California \\
\hline Laos & 14,100 & California \\
\hline Afghanistan & 7,000 & California \\
\hline Cambodia & 4,200 & California \\
\hline Eritrea & 2,700 & California \\
\hline Ethiopia & 2,500 & California \\
\hline Romania & 2,100 & California \\
\hline USSR, ns & 1,600 & California \\
\hline Latvia & 600 & California \\
\hline Ukraine & 37,100 & New York \\
\hline Russia & 23,500 & New York \\
\hline Uzbekistan & 9,800 & New York \\
\hline Byelorussia & 9,300 & New York \\
\hline Moldavia & 4,900 & New York \\
\hline Azerbaijan & 2,000 & New York \\
\hline Kazakhstan & 1,600 & New York \\
\hline Albania & 1,000 & New York \\
\hline Georgia & 800 & New York \\
\hline Somalia & 24,500 & Minnesota \\
\hline Liberia & 4,200 & Minnesota \\
\hline Serbia & 1,100 & Minnesota \\
\hline Syria & 1,800 & Maryland \\
\hline Sierra Leone & 500 & Maryland \\
\hline Cuba & 16,500 & Florida \\
\hline Hungary & 900 & Florida \\
\hline Burma & 11,800 & Indiana \\
\hline Bosnia & 10,900 & Missouri \\
\hline Bhutan & 9,100 & Ohio \\
\hline Congo & 4,100 & Texas \\
\hline Sudan & 2,400 & Virginia \\
\hline Croatia & 800 & Connecticut \\
\hline Bulgaria & 400 & Georgia \\
\hline
\end{tabular}

Source: CMS estimates of refugees derived from 2016 ACS; see text. 


\section{Findings}

The study analyzes the achievements, diverse contributions, and integration outcomes of refugees in three ways. First, it compares the household and demographic characteristics (Table G) and the economic characteristics (Table H) of refugees that arrived between 1987 and 2016, to comparable data for non-refugees, the foreign born, and the total US population. Second, it explores the characteristics of refugees by three periods of entry, and compares those estimates to the foreign born and the total US population (Table I). Third, it examines the characteristics of refugees - measured in 2000 and again in 2016 - that arrived from the former Soviet Union between 1987 and 1999 (Table J). Its findings largely align with earlier studies that detail the socioeconomic attainment of refugees over time. ${ }^{21}$

Refugees arrive with few (if any) financial resources and are responsible for repaying to the US Department of State their travel loans to resettle to the United States, which the overwhelming majority do over five years (DOS/PRM 2018c). Many arrive with poor English language skills and low educational attainment (Potocky-Tripodi 2004; Connor 2010). ${ }^{22}$ Some suffer from discrimination (NASEM 2015, 132). Most struggle economically and socially in the years immediately following their arrival.

Not surprisingly, the median household income of the 1.1 million refugees in CMS's sample which includes arrivals over a 30-year period - lags behind that of the non-refugee population $(\$ 43,000$ versus $\$ 45,000)$, the foreign born $(\$ 56,000)$, and the total US population $(\$ 52,800)$ (Table G). This may explain the slightly higher poverty rate and the higher use of food stamps and Medicaid by refugees, compared to these other populations. The high percentage of refugees who have reached retirement age, relative to the other three groups, explains refugees' comparatively higher usage of Medicare.

Overall, refugees have integrated impressively. Thirty-five percent of refugee households have mortgages, 63 percent have US-born children, 40 percent are married to US citizens, and 67 percent have naturalized (Table G). ${ }^{23}$ Refugees are also "more likely to appreciate the security of US citizenship" and "more likely to feel a strong sense of attachment or gratitude to the country that gave them refuge (citations omitted)" (NASEM 2015, 174).

21 These studies employ a range of methods and models to estimate the number of refugees and their economic and fiscal impact.

22 For this reason, outcome-oriented studies only examine the early years following resettlement, when refugees' economic contributions of refugees are lowest and their public benefit use is highest (O'Brien and Raley 2018). Similarly, these studies count the education of refugee children as a fiscal cost, but fail to consider their long-term contributions to the nation's economy, or they count only refugees' tax contributions, not their spending or business ownership.

23 Other studies find that refugees naturalize at higher rates than comparable non-refugees (Kallick and Mathema 2016; NAE 2017; Bernstein 2018). 
Table G. Household and Demographic Characteristics of the CMS Sample of Refugees Compared to Three Other Populations: 2016

(Numbers in thousands)

Household and demographic

characteristics
- represents zero, not relevant, or not available Arrived in 1987 to 2016 period

\begin{tabular}{|c|c|c|}
\hline Refugees & $\begin{array}{l}\text { Non- } \\
\text { refugees }\end{array}$ & $\begin{array}{r}\text { Foreign } \\
\text { born }\end{array}$ \\
\hline
\end{tabular}

(1)

(2)

(3)

\section{Household characteristics}

Total population

Number of households

1,089

664

1,089

32,116

323,128

Average household size

1.6

990

16,333

126,940

Median household income

Percent at or above poverty threshold

$\$ 43,000$

1.1

2.0

2.5

$78 \%$

$\$ 45,000$

$\$ 56,000$

$\$ 52,800$

Percent of households that have a mortgage

$35 \%$

$82 \%$

$80 \%$

$84 \%$

Percent of households receiving food stamps

$27 \%$

$36 \%$

$33 \%$

$37 \%$

Percent of children in household who are US-born

(children can be any age)

$63 \%$

$18 \%$

$16 \%$

$12 \%$

\section{Demographic characteristics}

Years in the United States

Total

1,089

Less than 15

$36 \%$

15 to 24

$42 \%$

25 or more

$22 \%$

Percent male

$48 \%$

$76 \%$

$73 \%$

Marital status

Total 15 years and older

Percent married

Percent married to US citizens

Age

Total

1,089

1,089

32,116

323,128

Under 18

$6 \%$

18 to 64

$82 \%$

$6 \%$

$8 \%$

$23 \%$

65 and over

$13 \%$

$87 \%$

$86 \%$

$62 \%$

Percent naturalized

$67 \%$

$8 \%$

$7 \%$

$15 \%$

Percent with any health insurance

$89 \%$

$42 \%$

$38 \%$

Percent receiving Medicaid

$36 \%$

$76 \%$

$75 \%$

$91 \%$

Percent receiving Medicare

$20 \%$

$20 \%$

$21 \%$

Source: Columns 1 and 2, CMS estimates, see text; Columns 3 and 4, from 2016 ACS. 
The economic characteristics of refugees - given their starting point - are equally impressive. The labor force participation and employment rates of the 1.1 million refugees in CMS's sample exceed those of the overall US population (Table $\mathrm{H}$ ). In addition, 10 percent of refugees are self-employed. ${ }^{24}$ Refugees' median personal income $(\$ 20,000)$ equals that of non-refugees and exceeds the income of the foreign born overall $(\$ 18,700)$. A higher percentage of refugees (38 percent) are skilled workers, than non-refugees (33 percent) or the foreign born (35 percent). Refugees regularly receive rave reviews from employers who credit them with enhancing or even saving their businesses. They are less likely to work in the jobs that new immigrants fill at high rates, such as construction, restaurants and food services, landscaping, services to buildings and dwellings, and private households.

\section{Letter from Steven A. Tetreault, Owner, The Drying Co. ThermalTec, to Commonwealth Catholic Charities in Newport News, Virginia, May 18, 2018}

"I wanted to reach out to you to express my appreciation for contacting us last year asking me if I needed to hire employees. I was in desperate need of installers for our products and services and had been struggling to find more workers. Our work is helping our customers make their homes more comfortable and energy efficient. So much of our work is in crawl spaces and attics. These are not the most desirable places to work.

You told me about the refugees and how you were helping them get started in this country. I have to admit I was unsure if it was a good idea. I met with seven refugees from Iraq and Afghanistan and hired them all the following week. I was so impressed with their work ethic and just how polite and pleasant they were with my other employees and customers that we hired another 5 shortly after.[...]

It's been a year now and all the original hires are still with me. I'm not sure how we would have made it through the year without them. We pride ourselves on high quality work and best solutions for our customers, and all the refugee employees have really helped us step up our game. I've come to know and love them all. They are working hard for their families and they work hard for me.

Some of them work with the US military and are absent from their jobs with us, but we are very proud of that too. Others have become US citizens while employed by us and others are working on theirs. They are proud people and do outstanding work every day.[...]

Last year in September at a convention we attended with our contracting network, Contractor Nation, they did a story on two of our refugees in front of almost two thousand contractors. The story was about the struggles in their homeland and how they desperately worked to come to the US and how, by building our business, we help people find jobs, buy homes, support families, and contribute to our communities and our country. Everyone was so moved. Many people asked me how they can help refugees get to their towns as they all are experiencing a shortage of labor too. I can't thank you enough for finding us and introducing us to such great people. It may have saved my business."

24 Other studies also find that refugees start businesses at a higher rate (13 percent) than the US-born population (9 percent) (NAE 2017), and that after 10 years, refugee business ownership rates rival those of natives (Kallick and Mathema 2016). 
Table H. Economic Characteristics of the CMS Sample of Refugees Compared to Three Other Populations: 2016

(Numbers in thousands)

Economic characteristics

Employment status

Total 16 years and older

Number in the labor force

Percent in the labor force

Percent employed

Percent self-employed

Percent unemployed

Median personal income

Percent of labor force that carpools

(ages 16 and over)

Percent that have access to a vehicle

Hours worked per week (employed only)

Skilled workers ages 16 and over

Skilled workers in the labor force

Percent that are skilled workers

Management, business, and financial

Computer, math., science and engineering

Social services, legal, education, arts and design

Healthcare practitioners and support

Percent that work in construction, restaurants and other food services, landscaping services, services to buildings and dwellings, crop production, and private households

- represents zero, not relevant, or not available Arrived in 1987 to 2016 period

\begin{tabular}{rrrr} 
Refugees & $\begin{array}{r}\text { Non- } \\
\text { refugees }\end{array}$ & $\begin{array}{r}\text { Foreign } \\
\text { born }\end{array}$ & $\begin{array}{r}\text { Total US } \\
\text { pop. }\end{array}$ \\
(1) & (2) & (3) & (4) \\
\hline
\end{tabular}

(4)

$\begin{array}{rrrr}1,039 & 1,037 & 30,159 & 257,997 \\ 703 & 753 & 21,395 & 162,950 \\ 68 \% & 73 \% & 71 \% & 63 \% \\ 64 \% & 69 \% & 67 \% & 60 \% \\ 7 \% & 8 \% & 7 \% & 6 \% \\ 5.9 \% & 5.2 \% & 5.2 \% & 5.7 \% \\ \$ 20,000 & \$ 20,000 & \$ 18,700 & \$ 23,000 \\ & & & \\ 8 \% & 9 \% & 10 \% & 5 \% \\ 88 \% & 91 \% & 90 \% & 94 \% \\ 39.6 & 39.5 & 39.3 & 39.1\end{array}$

\begin{tabular}{rrrr}
254 & 233 & 6,967 & 62,842 \\
$38 \%$ & $33 \%$ & $35 \%$ & $42 \%$ \\
$12 \%$ & $11 \%$ & $11 \%$ & $16 \%$ \\
$9 \%$ & $8 \%$ & $8 \%$ & $6 \%$ \\
$7 \%$ & $7 \%$ & $7 \%$ & $11 \%$ \\
$11 \%$ & $8 \%$ & $8 \%$ & $9 \%$ \\
& & & \\
$11 \%$ & & & \\
& $25 \%$ & $26 \%$ & $16 \%$ \\
\hline
\end{tabular}

Source: Columns 1 and 2, CMS estimates, see text; Columns 3 and 4, from 2016 ACS. 
The longer refugees reside in the United States, the more their public benefit use declines, ${ }^{25}$ and their integration, well-being, and US family ties increase (Table I). The refugees with the longest tenure exceed the most recent arrivals as measured by:

- households with mortgages (41 to 19 percent);

- English language proficiency (75 to 55 percent); ${ }^{26}$

- $\quad$ naturalization rates (89 to 24 percent);

- college education (66 to 32 percent); ${ }^{27}$

- labor force participation (68 to 61 percent); ${ }^{28}$

- employment (66 to 55 percent); ${ }^{29}$ and

- self-employment (14 to 4 percent).

Refugees from the middle group (1997 to 2006) had higher labor force and employment rates than refugees who arrived earliest (1987 to 1996), but this is likely due to the older age of the latter group (20 percent age 65 or over).

25 Capps et al. $(2015,25)$ found that 42 percent of refugees living in the United States less than five years participate in the food stamp program, compared to 16 percent of those with 20 or more years of residence. While 7 percent of recent arrivals receive cash welfare benefits, this figure falls to 3 percent for those with five or more years of residence (ibid.). Twenty-four percent of recent arrivals receive public health insurance, compared to 13 percent after 20 years. Other studies have found that:

- refugees' Medicaid and Supplemental Nutrition and Assistance Program (SNAP) participation decreases over time (HHS/ORR 2017, 16);

- there is little difference in welfare and SNAP uptake between refugees and the US-born (Evans and Fitzgerald 2017); and

- refugees use Social Security, Social Security Disability Insurance (SSDI), and Medicare at lower rates than the population average after 10 years, participate in the Temporary Assistance for Needy Families (TANF) program at similar levels as that of the total population, and use SNAP and Supplemental Security Income at higher rates (HHS 2017, 25).

26 Refugees learn English faster than comparable immigrants (NAE 2017). After 10 years, most refugees have become proficient in English (Kallick and Mathema 2016). After five years, only 15.2 percent of adults speak no English (HHS/ORR 2017).

27 Refugees who enter the United States prior to age 14 graduate from high school and attend college at the same rate as the US-born (Evans and Fitzgerald 2017). About 41.8 percent of refugees in Columbus, Ohio are enrolled in or have graduated from college, compared to 43 percent of the overall population (Community Research Partners 2015).

28 Refugees entering the United States between age 18 and 45, initially participate in the labor force at lower rates than the US-born (Evans and Fitzgerald 2017). After two years, their labor force participation rate equals that of the US population (HHS/ORR 2017). After six years, refugees overtake natives by this metric (Evans and Fitzgerald 2017). One study found that refugee employment rates rose from 17 percent in year one, to 63.5 percent by year three (State of Colorado, Office of Economic Security 2016). In Columbus, Ohio, refugees' labor force participation rate (81.8 percent) exceeded the region's average of 77.1 percent (Community Research Partners 2015). Male refugees (67 percent) work at higher rates than US-born men (62 percent) (Capps et al. 2015). Refugee and US-born women work at the same rate (54 percent) (ibid.). The labor force participation rates of refugee women and US natives converge after 10 years (Kallick and Mathema 2016).

29 Refugees also tend to have lower turnover rates than other employees (Kallick and Roldan 2018, 21), and often work in jobs that are unappealing to the US-born (NAE 2017). 
Table I. Selected Characteristics of CMS Sample of Refugees, by Period of Entry, Compared to Total US Population and Foreign Born that Entered 1987 to 2016

\begin{tabular}{|c|c|c|c|c|c|c|}
\hline \multirow{3}{*}{ Characteristics } & \multirow{3}{*}{$\begin{array}{r}\text { Total US } \\
\text { pop. } \\
\text { (1) }\end{array}$} & \multicolumn{2}{|c|}{$\frac{\text { Entered } 1987 \text { to }}{2016}$} & \multirow[b]{2}{*}{$\begin{array}{l}\text { Entered } \\
1987 \text { to } \\
1996\end{array}$} & \multirow[b]{2}{*}{$\begin{array}{r}\text { Entered } \\
1997 \text { to } \\
2006\end{array}$} & \multirow{3}{*}{$\begin{array}{r}\text { Entered } \\
2007 \text { to } \\
2016 \\
\text { (6) }\end{array}$} \\
\hline & & $\begin{array}{c}\text { Foreign } \\
\text { born }\end{array}$ & Total & & & \\
\hline & & (2) & (3) & (4) & (5) & \\
\hline Total population & 323,128 & 32,116 & 1,089 & 516 & 249 & 324 \\
\hline Median household income & $\$ 52,800$ & $\$ 56,000$ & $\$ 43,000$ & $\$ 50,000$ & $\$ 48,000$ & $\$ 31,200$ \\
\hline Median personal income & $\$ 23,000$ & $\$ 18,700$ & $\$ 20,000$ & $\$ 28,000$ & $\$ 21,600$ & $\$ 10,000$ \\
\hline $\begin{array}{l}\text { Percent of households } \\
\text { receiving food stamps }\end{array}$ & $12 \%$ & $16 \%$ & $27 \%$ & $18 \%$ & $25 \%$ & $46 \%$ \\
\hline $\begin{array}{l}\text { Percent of households that } \\
\text { have a mortgage }\end{array}$ & $37 \%$ & $33 \%$ & $35 \%$ & $41 \%$ & $38 \%$ & $19 \%$ \\
\hline $\begin{array}{l}\text { Percent of households at or } \\
\text { above poverty threshold }\end{array}$ & $84 \%$ & $80 \%$ & $78 \%$ & $86 \%$ & $83 \%$ & $62 \%$ \\
\hline $\begin{array}{l}\text { Percent of children in } \\
\text { household who are US-born } \\
\text { (children can be any age) }\end{array}$ & - & $73 \%$ & $63 \%$ & $79 \%$ & $72 \%$ & $29 \%$ \\
\hline $\begin{array}{l}\text { Percent with access to } \\
\text { computer and the internet }\end{array}$ & $75 \%$ & $73 \%$ & $77 \%$ & $82 \%$ & $80 \%$ & $67 \%$ \\
\hline Age in 2016 & & & & & & \\
\hline Total & 323,128 & 32,116 & 1,089 & 516 & 249 & 324 \\
\hline Under 18 & $23 \%$ & $8 \%$ & $6 \%$ & - & $2 \%$ & $17 \%$ \\
\hline 18 to 64 & $62 \%$ & $86 \%$ & $82 \%$ & $80 \%$ & $90 \%$ & $77 \%$ \\
\hline 65 and over & $15 \%$ & $7 \%$ & $13 \%$ & $20 \%$ & $8 \%$ & $6 \%$ \\
\hline Years in the United States & & & & & & \\
\hline Total & - & 32,116 & 1,089 & 516 & 249 & 324 \\
\hline Less than 15 years & - & $51 \%$ & $36 \%$ & - & $28 \%$ & $100 \%$ \\
\hline 15 to 24 years & - & $35 \%$ & $42 \%$ & $54 \%$ & $72 \%$ & - \\
\hline 25 years or more & - & $13 \%$ & $22 \%$ & $46 \%$ & - & - \\
\hline $\begin{array}{l}\text { Percent that speak English } \\
\text { well, very well, or only English } \\
\text { ( } 5 \text { years and over) }\end{array}$ & - & $70 \%$ & $69 \%$ & $75 \%$ & $76 \%$ & $55 \%$ \\
\hline $\begin{array}{l}\text { Percent with some college or a } \\
\text { degree ( } 18 \text { years or over) }\end{array}$ & $60 \%$ & $49 \%$ & $53 \%$ & $66 \%$ & $51 \%$ & $32 \%$ \\
\hline Percent naturalized & - & $38 \%$ & $67 \%$ & $89 \%$ & $77 \%$ & $24 \%$ \\
\hline
\end{tabular}


Table I. (Continued) Selected Characteristics of CMS Sample of Refugees, by Period of Entry, Compared to Total US Population and Foreign Born that Entered 1987 to 2016 (Numbers in thousands) - zero, rounds to zero, or not applicable

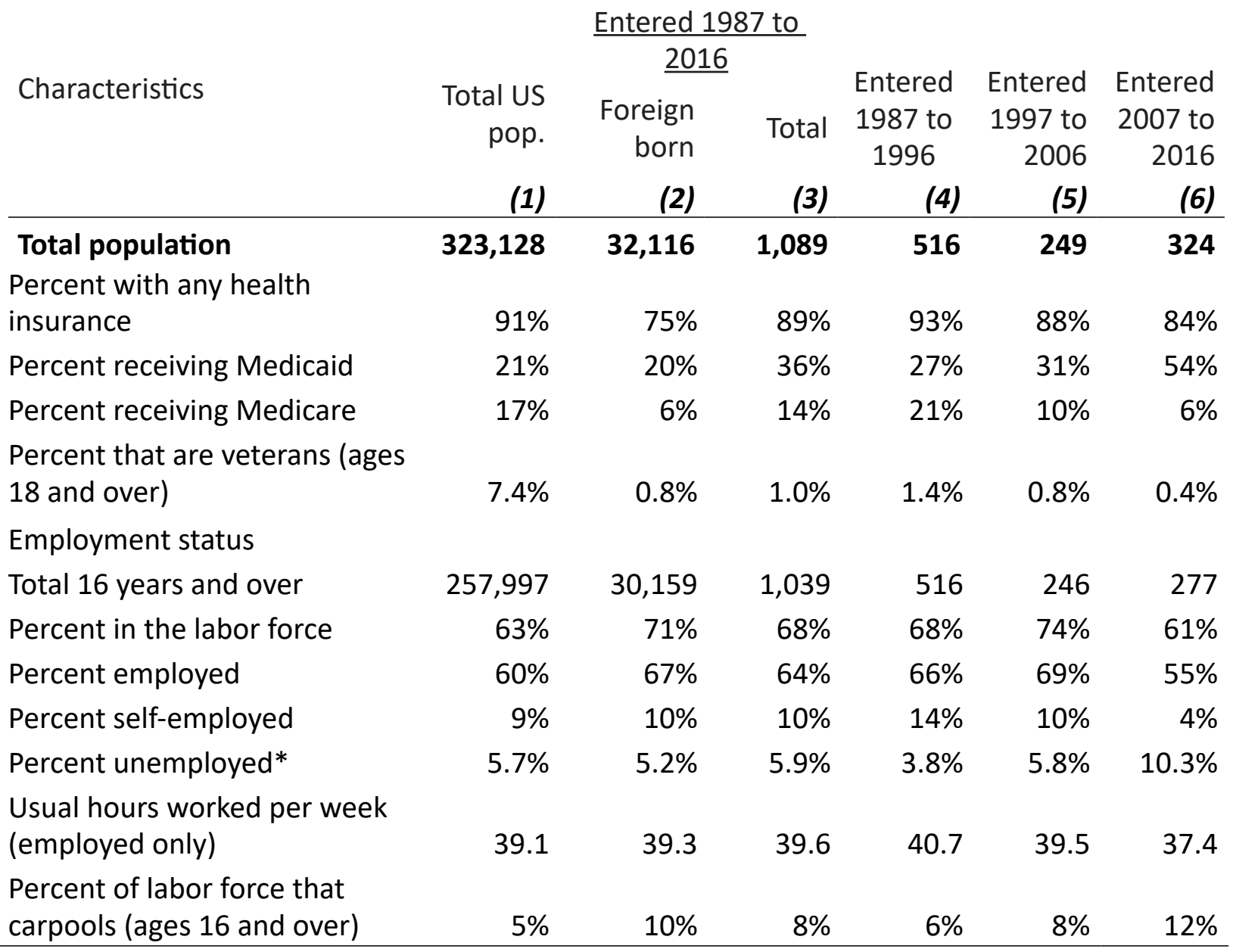

Source: Columns 1 and 2 from 2016 ACS; columns 3 to 6, CMS sample of refugees from 2016 ACS, see text.

*Includes people unemployed or seeking work. 
Table J. Selected Characteristics of Refugees from Former USSR that Arrived in the 1987 to 1999 Period, Enumerated in the 2000 ACS and the 2016 ACS

(Numbers in thousands)

\begin{tabular}{|c|c|c|}
\hline \multirow{3}{*}{ Characteristics } & \multicolumn{2}{|c|}{$\frac{\text { Refugees from former USSR in CMS sample, }}{\text { arrived } 1987 \text { to } 1999}$} \\
\hline & In 2000 ACS data & In 2016 ACS data \\
\hline & (1) & (2) \\
\hline Refugees from former USSR, ${ }^{*}$ entered 1987 to 1999 & 510 & 336 \\
\hline Average household size & 2.1 & 1.4 \\
\hline Median household income & $\$ 31,000$ & $\$ 53,000$ \\
\hline Median personal income & $\$ 10,700$ & $\$ 31,000$ \\
\hline Percent at or above poverty threshold & $79 \%$ & $86 \%$ \\
\hline Percent of households that have a mortgage & $30 \%$ & $40 \%$ \\
\hline Percent of households receiving food stamps & $27 \%$ & $18 \%$ \\
\hline \multicolumn{3}{|l|}{ Years in the United States } \\
\hline Total & 510 & 336 \\
\hline Less than 15 years & $100 \%$ & - \\
\hline 15 to 24 years & - & $62 \%$ \\
\hline 25 years or more & - & $38 \%$ \\
\hline $\begin{array}{l}\text { Percent that speak English well, very well, or only English ( } 5 \\
\text { years and over) }\end{array}$ & $74 \%$ & $79 \%$ \\
\hline Percent with some college or a degree ( 18 years or over) & $68 \%$ & $80 \%$ \\
\hline Percent naturalized & $47 \%$ & $89 \%$ \\
\hline Percent married & $56 \%$ & $58 \%$ \\
\hline Percent married to US citizens & $33 \%$ & $51 \%$ \\
\hline \multicolumn{3}{|l|}{ Age (in years) } \\
\hline Total & 510 & 336 \\
\hline Under 18 & $17 \%$ & - \\
\hline 18 to 64 & $69 \%$ & $78 \%$ \\
\hline 65 and over & $13 \%$ & $22 \%$ \\
\hline \multicolumn{3}{|l|}{ Employment status } \\
\hline Total 16 years and over & 436 & 336 \\
\hline Percent in the labor force & $59 \%$ & $69 \%$ \\
\hline Percent employed & $57 \%$ & $66 \%$ \\
\hline Percent self-employed & $11 \%$ & $15 \%$ \\
\hline Percent unemployed & $4.6 \%$ & $4.2 \%$ \\
\hline Percent skilled workers (ages 16 and over, in the labor force) & $33 \%$ & $38 \%$ \\
\hline
\end{tabular}

Source: 2000 and 2016 ACS. See text for methods of computation.

* Countries included in the data in this table: Armenia, Azerbaijan, Byelorussia, Georgia, Latvia, Lithuania, Moldova, Russia, Ukraine, Uzbekistan, and USSR, ns. 
The most telling comparison may be between long-term refugees and the total US population, which consists mostly of the native born. The report finds that the refugees who arrived between 1987 and 1996 exceed natives in median personal income, as well as in homeownership (41 versus 37 percent with a mortgage), percent above the poverty line (86 to 84 percent), access to a computer and the internet ( 82 to 75 percent), and health insurance (93 to 91 percent). ${ }^{30}$

In lay terms, over a relatively short period of time, the refugees in CMS's sample - who arrived penniless - became US citizens, homeowners, English speakers, employees, business owners, college graduates, insured, and computer literate at very high rates. These findings are all the more impressive because they occurred among a large population of refugees comprised of all nationalities who arrived from 1987 to $2016,{ }^{31}$ and not just highly achieving groups.

CMS also examined the characteristics of refugees - measured in 2000 and again in 2016 - from the former Soviet Union in the 1987 to 1999 period. ${ }^{32}$ Between 2000 and 2016:

- the median household income of these refugees increased from $\$ 31,000$ to $\$ 53,000$;

- median personal income nearly tripled, from $\$ 10,700$ to $\$ 31,000$;

- the percent of households with a mortgage grew from 30 to 40 percent;

- receipt of food stamps fell from 27 to 18 percent;

- English language proficiency rose;

- refugees with a college degree or some college increased from 68 to 80 percent;

- $\quad$ naturalization rates nearly doubled, from 47 to 89 percent; 33

- $\quad$ marriage to a US citizen rose from 33 to 51 percent; and

- the rates of labor force participation (59 to 69 percent), employment (57 to 66 percent), selfemployment (10 to 15 percent), and skilled workers (33 to 38 percent) all increased (Table J).

In short, this group successfully integrated over a 16-year period through citizenship, homeownership, work, income, education, and English language proficiency. Although not the subject of this study, the socioeconomic attainment of the children of refugees will likely surpass that of their parents.

30 Refugees' income grows faster over time than that of other foreign-born groups (NAE 2017). The median household income of refugees who have lived in the United States for 25 years or more is $\$ 67,000, \$ 14,000$ more than the US average (ibid.). Refugee household income converges with the overall US population's average income after 10 years of residence (HHS 2017).

31 National origin, rather than state of settlement, seems more highly correlated with socioeconomic success and integration (Fix, Hooper, and Zong 2017, 20).

32 Notably, this population fell from 510,000 to 336,000 between 2000 and 2016. This suggests that roughly onethird emigrated (from the United States) and a small number died. For the total foreign born that arrived in 1987 to 1999 , the comparable rate of "loss" was 20 percent. The relatively higher emigration rate of refugees from the former Soviet Union could reflect long-term improvements in the conditions in their countries.

33 By way of contrast, the percentage of those naturalized by 2016 for all foreign born who entered from 1987 to 1999 was 57 percent. 
Finally, refugees promote the nation's competitiveness and security through their linguistic skills and diversity (Table K). In a globalized world, language proficiency is essential to "trade, public safety, human security, cultural exchange, and international cooperation" (Heyman 2013, 70). The US armed forces, and intelligence and law enforcement agencies rely on the language skills of refugees and immigrants to meet US military, counterterrorism, and law enforcement objectives (Kerwin and Stock 2007, 401).

Table K. Language Spoken at Home: Refugees in CMS Sample

Based on 2015 ACS data - see note below. Languages spoken by fewer than 5,000 refugees are not shown.

\begin{tabular}{lr} 
Language spoken & Number \\
\hline Total & $\mathbf{1 , 0 8 8 , 6 0 0}$ \\
Russian & 269,600 \\
English & 98,100 \\
Arabic & 91,600 \\
Serbo-Croatian, Yugoslavian, Slavonian & 89,100 \\
Vietnamese & 80,800 \\
Hamitic & 66,700 \\
Burmese, Lisu, Lolo & 48,000 \\
Ukrainian, Ruthenian, Little Russian & 43,900 \\
Dravidian & 38,900 \\
Tibetan & 33,500 \\
Spanish & 25,100 \\
Indonesian & 24,500 \\
Armenian & 23,000 \\
Amharic, Ethiopian, etc. & 22,700 \\
Thai, Siamese, Lao & 19,100 \\
Chinese & 16,100 \\
Near East Arabic dialect & 14,300 \\
Rumanian & 13,600 \\
Persian, Iranian, Farsi & 12,500 \\
Sub-Saharan Africa & 10,400 \\
French & 8,600 \\
Other Persian dialects & 7,800 \\
All other East/Southeast Asian & 7,200 \\
\hline Source: & 23,600 \\
\hline
\end{tabular}

Source: 2015 ACS; refugee data compiled as described in the text for 2016, then controlled to total refugees in 2016.

Note: ACS data for 2015 was used for this table because language data are not yet available for 2016 in IPUMS. 


\section{Voluntary Agencies and the Catholic Experience}

Resettled refugees strongly benefit from USRAP's public/private partnerships. In particular, the Office of Refugee Resettlement (ORR) partners with voluntary agencies to carry out refugee assistance programs and provide core resettlement services. Since 1980, the United States Conference of Catholic Bishops, Migration and Refugee Services (USCCB/MRS) has settled nearly one-third of all refugees in the United States - more than any nation other than the United States (Kerwin 2014, 128) -through the national network of Catholic Charities agencies.

The resettlement program has experienced backlash in some communities based on the concern that refugees can strain local resources (Brown and Scribner 2014). Yet voluntary agencies supplement federal funding with significant financial and in-kind support to refugees. One study, for example, found that the federal government funded only 39 percent of the cost of resettling refugees during their first 90 days in the country (LIRS 2008).

Beyond the services and resources they provide, voluntary agencies promote refugee integration through mobilizing communities in support of refugees. To that end, USCCB/MRS created the Parishes Organized to Welcome Refugees (POWR) program, which recruits volunteers to mentor, train, and assist refugees. Since 2010, POWR has provided modest grants to 52 Catholic Charities agencies, which have allowed them to recruit more than 14,500 volunteers, to establish more than 450 parish and community partnerships, and to generate $\$ 8.1$ million in cash and inkind donations and services on behalf of 31,000 refugees from over 50 countries (Sturm n.d.). Parishes have helped refugees to meet their initial needs for food, housing, furnishings, clothing, orientation, language training, employment, and medical assistance. At the most basic level, POWR has enabled the formation of new and lasting friendships between refugees and members of host communities and has promoted their integration.

\section{Omar Al-Muqdad}

Just seven years ago I would have never imagined myself as a refugee. But since the revolution started in Syria, my country has been engulfed in what it seems like a never-ending war, and my life has been changed forever. When I arrived in the United States in 2012, and I was given my first piece of identification, I felt as if a whole new person had been reborn. When I left Syria, I had nothing but my broken heart. I was no longer welcomed in my country. The tyrant regime had taken away my loved ones, my identity, and my home.

Before the Syrian revolution started, I was a hardworking journalist, but it was almost impossible to practice my profession without constant harassment by the authorities. At one point, I decided to establish a private newspaper, but it was shut down after I wrote an article critical of the government. The Syrian regime used to imprison anyone who dared to criticize the government or question its legitimacy. Unfortunately I was one of the people incarcerated for speaking my mind about the regime.

My trial took place in a military court and I was sentenced to three years in prison. I spent most of it in a terrible military prison where I was subjected to systematic torture for four months. My torture took many different forms. When my time in prison had ended, they took away my ID and passport and threw me out of prison. I went back to my work, but this time secretively and underground. 
In 2011, when the unrest broke out in my hometown of Dara'a, all of us were exposed to barbaric treatment by the Syrian armed forces. I witnessed family members, friends and neighbors getting detained or killed by the Syrian regime. In one protest, the armed forces stormed the crowd and started shooting randomly at us. One bullet missed me by few inches, but landed in my friend's chest. I had only two possibilities in that country, death or detention, and I fled from Syria.

In the darkest of days, and in the hardest of times, the people who show up in your life and offer help mean everything to you. They provide you with hope, and a sense that there may be a future for you. Catholic Charities cared, they listened, and they offered me all kinds of help. They followed up and checked on me regularly. They valued me as a human being with dignity, which is more important than food and aid.

I was so fortunate to have found myself a new home in Arkansas, where I experienced the true hospitality and generosity of the South. I was so pleased by how friendly people were. In the little town of Fayetteville, I was welcomed with open arms by everyone I met, and I became part of the community in a matter of weeks. Being in the United States, "the land of the free," gave me a new chance in life, a new beginning. I was finally able to feel the true meaning of freedom. I found the kind of freedom that I needed the most as a human being and, of course, as a journalist. The kind of freedom I wish for all my people who have been suffering bombs, death, and destruction.

My future looks so bright right now, and I have many plans underway - to continue my education and continue my work in journalism and in making documentary films. I'm now in the final stages of producing a documentary about Thomas Jefferson and there is a short film on its way as well: it's about my own story.

POWR honors Pope Francis's call "to foster a culture of encounter in every way possible by increasing opportunities for intercultural exchange, documenting and disseminating best practices of integration, and developing programmes to prepare local communities for integration processes" (Francis 2018b).

The work of voluntary agencies builds on the initiative and dreams of refugees. Pope Francis memorably said that refugees are not "pawns on the chessboard of humanity" (Francis 2013), but are agents in their own lives, with hopes and aspirations. To that end, a small but growing number of Catholic Charities agencies support refugee entrepreneurial activities through microenterprise programs that provide training and access to small, credit-building loans for refugees that want to start their own business. Catholic Charities USA has partnered with the SunTrust Foundation to support agencies in piloting microbusiness programs.

The Refugee Assistance in Microenterprise (AIM) Project of Catholic Charities Diocese of St. Petersburg, for example, provides low-interest loans to refugee entrepreneurs in Hillsborough and Pinellas counties in Florida, but it has a wider objective as well, to foster the development of refugees in all their dimensions.

For the last 10 years, Catholic Charities of Camden's Small Business program has helped refugees and immigrants to start dozens of businesses, including food services, lawn care, drain clearing, auto repair, dog grooming, and janitorial work. The process begins with the development of a business plan. The program then assists refugees to access a microloan fund for business start-up 
costs. As necessary, Catholic Charities also works with refugees to help repair their credit. Yasmin, an immigrant from Burma, is one of the program's success stories. He was able to save the money to buy a franchise and attend the company's training, as well as to secure a $\$ 15,000$ loan to start the business. Today, he owns two sushi franchises and fully supports his family.

Catholic Charities of Oregon, in turn, assisted Mohammad to fulfill his lifelong dream of becoming a business owner. While living in Malaysia after leaving his troubled nation of Burma, Mohammad helped run a business with a family who took him in as their own. However, he could not obtain legal status in Malaysia. "After living in Malaysia for 22 years," he says, "it felt like my own country, but the government would always reject me. Officials would come in all the time, and take everything over."

After coming to the United States as a refugee, Mohammad worked hard and used his business skills to start a new life. He now runs a grocery store and works for Catholic Charities and local hospitals as a Rohingyan interpreter. His life is still full of challenges, but he has the opportunity to succeed. "I came to the US by myself," he says. "My father still lives in Bangladesh, and I lost my mom in 2009. I've been separated from my family for 23 years. I never had a chance to see them after I left, because I was never given the legal status to see them. Since 2014, I have been given a chance to go and see them, after 23 years. It has been challenging, to not see them for so long, but by coming to this country, I will finally have the chance."

\section{Conclusions and Recommendations}

Over its 38-year history, USRAP has resettled more than three million refugees, making it one the largest, most successful humanitarian initiatives in US history (Brown and Scribner 2014, 102). The administration's attacks on the program require a return to first principles. Beyond the economic, cultural, and social contributions of refugees, the US refugee program advances the nation's interests because it:

- $\quad$ saves the lives of some of the world's most vulnerable persons;

- continues "America's tradition as a land that welcomes peoples from other countries" and shares the "responsibility of welcoming and resettling those who flee oppression" (Reagan 1981);

- promotes a "stable and moral world" (Helton 2002, 120);

- reduces spontaneous, unregulated arrivals and encourages developing nations to remain engaged in refugee protection (Gammeltoft-Hansen and Tan 2017, 42-43);

- promotes cooperation from individuals, communities, and nations that are central to US military and counterterrorism strategies; ${ }^{34}$ and

- bridges the gap between US values and practices.

The refugee resettlement program has long struggled with coordination challenges, diverse goals, a narrow metric for integration, attenuated screening protocols, and insufficient federal funding (Brown and Scribner 2014, 110-112). The following recommendations would significantly strengthen the program:

34 Brief for Retired Generals and Admirals of the US Armed Forces in Support of Respondents at 19-21, Trump v. Hawaii, No. 1 7-965 (Mar. 30, 2018). 
- The program should improve information sharing between its constituent agencies, better coordinate its admission and resettlement programs, and more effectively serve vulnerable refugees. ${ }^{35}$

- The federal government should seek to reconcile the program's diverse, sometimes conflicting, programmatic goals, including protection of the most vulnerable and refugee integration (ibid., 107).

- The federal government should also broaden the program's overarching and legitimate focus on self-sufficiency through early employment, to a model that comprehensively assesses each refugee's needs and seeks to develop the skills, knowledge, credentials, and human capital that will advance their long-term prospects (GAO 2012, 39; Kerwin 2012, 10; Brown and Scribner 2014, 107). ${ }^{36}$

- Congress should expedite refugee integration by allowing refugees to enter the United States with LPR status, rather than requiring them to adjust to LPR status after one year.

- The participating federal agencies should shorten the refugee screening process - without sacrificing its rigor - by aligning the expiration dates of health and security screenings, and it should expedite the admission of the family members of refugees (Kerwin 2012, 7; Nezer 2014, 129).

- Congress should pass legislation to permit the private sponsorship of refugees as a complement to (not a replacement for) the current system while maintaining refugees' access to public programs and benefits that promote their integration and well-being.

- Federal funding for the program - which has fallen sharply since 1980 - should be increased to alleviate the costs borne by local communities and resettlement agencies. ${ }^{37}$

- The US Department of Education and US Department of Labor should work with states to establish re-credentialing programs that would enable refugees to use their skills to transition into employment in their respective fields while addressing key US labor shortages.

- The administration should expand the Refugee Microenterprise Development program within HHS, which provides microloans and technical assistance to assist refugee entrepreneurs establish new businesses.

35 As it stands, insufficient information sharing between USRAP's participating federal agencies, Congress, states, localities, and nongovernmental stakeholders "negatively affect planning, placement decisions, and provision of support services to refugees with special needs and vulnerabilities" (Brown and Scribner 2014, 114-16).

36 An exhaustive report by the McKinsey Global Institute on the economic benefits of migration concludes that integration policies should address health care, housing, education, and social and civic issues holistically. Integration policies that address only employment issues disadvantage the already disadvantaged (MGI 2016, 12).

37 In 1980, the federal government fully reimbursed states for the welfare and medical costs of refugees and provided benefits to refugees for their first 36 months in the country (US Select Commission on Immigration and Refugee Policy1981, 181), and provided refugee cash assistance (RCA) and refugee medical assistance (RMA) over the same period. By 1991, the federal government had reduced the period of RCA and RMA benefits to eight months (Nezer 2014, 138). By October 1990, the federal government stopped covering the state share (for refugees) of Aid to Families with Dependent Children, Medicaid, and SSI (Brown and Scribner 2014, 109). 
These recommendations would address longstanding programmatic challenges, but they do not justify efforts to dismantle the program or otherwise diminish the federal government's responsibility for it. As it stands, the program's virtues still far exceed its shortcomings. Overall, USRAP should be strengthened and refugee admissions increased, as part of a broad recommitment to US development, humanitarian, and protection programs. Refugees "share a legitimate desire for knowing and having, but above all for being more" (Francis 2013). They should not be viewed as a burden or threat, but as people teeming with possibility and potential who - if given the chance - will continue to strengthen and revitalize our nation.

\section{Appendix A}

Table A-1. Summary of Data Selection for Refugees in This Report

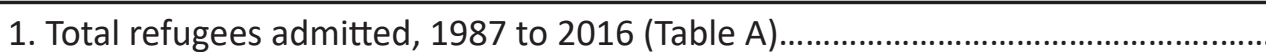

$2,270,000$

2. Total refugees in the 39 countries that had at least one year in which refugees

exceeded arriving LPRs by at least a 2 to 1 ratio.

3. Sum of the country/year cells that had at least a 2 to 1 ratio of refugees to arriving LPRs (this is the number that would have been counted in 2016 if none had died, departed, or been omitted from the ACS).

4. Refugees, as selected in 3 above, that were counted in the 2016 ACS.

$1,088,000$

5. Percentage counted in $2016^{38}$

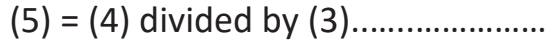

$79 \%$

Source: see text.

\section{References}

Bernstein, Hamutal. 2018. Bringing Evidence to the Refugee Integration Debate. Washington, DC: Urban Institute. https://www.urban.org/research/publication/bringing-evidencerefugee-integration-debate/view/full_report.

Brown, Anastasia, and Todd Scribner. 2014. "Unfulfilled Promises, Future Possibilities: The Refugee Resettlement System in the United States." Journal on Migration and Human Security 2(2): 101-20. http://dx.doi.org/10.14240/jmhs.v2i4.40.

Bruno, Andorra. 2017. "Refugee Admissions and Resettlement Policy." Washington, DC: Congressional Research Service. http://fas.org/sgp/crs/misc/RL31269.pdf.

Capps, Randy, Kathleen Newland, Susan Fratzke, Susanna Groves, Gregory Auclair, Michael Fix, and Margie McHugh. 2015. The Integration Outcomes of U.S. Refugees: Successes and Challenges. Washington, DC: Migration Policy Institute. https://www.migrationpolicy. org/research/integration-outcomes-us-refugees-successes-and-challenges.

Chmura Economics \& Analytics. 2017. "Economic Impact of Refugees in the Cleveland Area: Calendar Year 2016." http://rsccleveland.org/wp-content/uploads/2016/12/ EconomiclmpactStudy2017FINAL.pdf.

38 The percentage of 79 percent, counted in 2016, line 5, does not represent undercount. It indicates that approximately 20 percent of the refugees that arrived in the 1987 to 2016 period had emigrated by 2016 (includes a small number that died). 
Community Research Partners. 2015. "Impact of Refugees in Central Ohio: 2015 Report." Columbus, Ohio: US Together, Community Refugee \& Immigration Services, World Relief Columbus, and the City of Columbus. http://ustogether.us/wp-content/uploads/2016/12/IMPACTOF-REFUGEES-ON-CENTRAL-OHIO_2015SP.pdf.

Connor, Phillip. 2010. "Explaining the Refugee Gap: Economic Outcomes of Refugees versus Other Immigrants." Journal of Refugee Studies 23(2): 377-97.

CRSA (Coalition of Refugee Services Agencies). 2016. "Refugees and Immigrants in Georgia: The Facts." http://newamericanpathways.org/wp-content/uploads/2014/07/FactSheet-2016.pdf.

DHS (Department of Homeland Security). 2003. "2002 Yearbook of Immigration Statistics." Washington, DC: DHS Office of Immigration Statistics.

_. 2014. 2013 Yearbook of Immigration Statistics. Washington, DC: DHS Office of Immigration Statistics. http://www.dhs.gov/sites/default/files/publications/ois_yb_2013.pdf.

DOS/PRM (US Department of State, Bureau of Population, Refugees, and Migration). 2018a. "Historical Arrivals Broken Down by Region (1975-Present)." Washington, DC: DOS/PRM. http://www.wrapsnet.org/s/Graph-Refugee-Admissions-FY2018_04_30-|4jc.xls.

_. 2018b. "Arrivals by Region as of May 11, 2018." http://www.wrapsnet.org/s/Arrivals-byPA-Region_2018_05_11.xls.

_. 2018c. "US Refugee Admissions Program FAQs." https://www.state.gov/j/prm/releases/ factsheets/2018/277838.htm.

Evans, William N. and Daniel Fitzgerald. 2017. "The Economic and Social Outcomes of Refugees in the United States: Evidence from the ACS." NBER Working Paper 23498. Washington, DC: NBER (National Bureau of Economic Research).

Fix, Michael, Kate Hooper, and Jie Zong. 2017. "How Are Refugees Faring? Integration at US and State Levels." Washington, DC: Migration Policy Institute. https://www.migrationpolicy. $\mathrm{org} /$ research/how-are-refugees-faring-integration-us-and-state-levels.

Francis (His Holiness Pope Francis). 2013. "Message of His Holiness Pope Francis for the World Day of Migrants and Refugees: Towards a Better World (2014)." http://www.vatican.va/ holy_father/francesco/messages/migration/documents/papa-francesco_20130805_ world-migrants-day_en.html.

2018a. Apostolic Exhortation, Gaudete Exsultate (Rejoice and Be Glad). http://w2.vatican. va/content/francesco/en/apost_exhortations/documents/papa-francesco_esortazioneap_20180319_gaudete-et-exsultate.html.

. 2018b. "Message of His Holiness Pope Francis for the 104th World Day of Migrants and Refugees 2018: 'Welcoming, Protecting, Promoting and Integrating Migrants and Refugees."' https://w2.vatican.va/content/francesco/en/messages/migration/ documents/papa-francesco_20170815_world-migrants-day-2018.html. 
Gamboa, Suzanne, and Daniella Silva. 2018. "Anguish' at the border as immigrant children are separated from parents." NBC News, May 22. https://www.aol.com/article/ news/2018/05/22/anguish-at-the-border-as-immigrant-children-are-separated-fromparents/23440751/.

Gammeltoft-Hansen, Thomas, and Nikolas F. Tan. 2017. "The End of the Deterrence Paradigm? Future Directions for Global Refugee Policy." Journal on Migration and Human Security 5(1): 28-56. https://doi.org/10.14240/jmhs.v5i1.73.

GAO (US Government Accountability Office). 2012. "Refugee Resettlement: Greater Consultation with Community Stakeholders Could Strengthen Program." GAO-12-729. Washington, DC: GAO. https://www.gao.gov/assets/600/592975.pdf.

Helton, Arthur C. 2002. The Price of Indifference: Refugees and Humanitarian Action in the New Century. Oxford: Oxford University Press.

Heyman, Josiah McC. 2013. "A Voice of the US Southwestern Border: The 2012 'We the Border: Envisioning a Narrative for Our Future' Conference." Journal on Migration and Human Security 2(2): 50-75. https://doi.org/10.14240/imhs.v1i2.9.

HHS (US Department of Health and Human Services). 2017. The Fiscal Costs of the U.S. Refugee Admissions Program at the Federal, State, and Local Levels, from 2005-2014. Washington, DC: HHS. https://assets.documentcloud.org/documents/4056060/Refugee-Report-Draft. pdf.

HHS/ORR (US Department of Health and Human Services, Office of Refugee Resettlement). 2017. Annual Report to Congress: Fiscal Year 2015. Washington, DC: HHS/ORR. https://www.acf. hhs.gov/orr/resource/office-of-refugee-resettlement-annual-report-to-congress-2015.

IDMC and NRC (Internal Displacement Monitoring Centre and Norwegian Refugee Council). 2017. Global Report on Urban Displacement. Geneva: IDMC. http://www.internal-displacement. org/sites/default/files/publications/documents/20170522-GRID.pdf.

Kallick, David Dyssegaard, and Silva Mathema. 2016. "Refugee Integration in the United States." Washington, DC: Center for American Progress and Fiscal Policy Institute. https://cdn. americanprogress.org/wpcontent/uploads/2016/06/15112912/refugeeintegration.pdf.

Kallick, David Dyssegaard, and Cyierra Roldan. 2018. "Refugees as Employees: Good Retention, Strong Recruitment." New York: Fiscal Policy Institute and Tent Foundation. http:// fiscalpolicy.org/refugees-as-employees-good-retention-strong-recruitment.

Kantor, Jodi, and Catrin Einhorn. 2016. "Who Else Can Sponsor a Refugee? The List Is Limited for Now." New York Times, June 30. https://www.nytimes.com/2016/07/01/world/refugeesprivate-sponsors.html.

Kerwin, Donald. 2010. "More than IRCA: US Legalization Programs and the Current Policy Debate." Washington, DC: Migration Policy Institute. https://www.migrationpolicy.org/research/ us-legalization-programs-by-the-numbers. 
- 2012. "The Faltering Refugee Protection System: Legal and Policy Responses to Refugees, Asylum-Seekers, and Others in Need of Protection." Refugee Survey Quarterly 31(1):1-33. https://doi.org/10.1093/rsq/hdr019.

-. 2015. "The US Refugee Protection System on the 35th Anniversary of the 1980 Refugee Act." Journal on Migration and Human Security 3(2): 205-54. https://doi.org/10.14240/ imhs.v3i2.49.

- 2016. "How Robust Refugee Protection Policies Can Strengthen Human and National Security." Journal on Migration and Human Security 4(3): 83-140. https://doi. org/10.14240/imhs.v4i3.64.

—. 2017. "The Besieged US Refugee Protection System: Why Temporary Protected Status Matters." CMS Essays. New York: Center for Migration Studies. http://cmsny.org/ publications/besieged-us-refugee-protection-system-temporary-protected-statusmatters/.

Kerwin, Donald, and Margaret D. Stock. 2007. "The Role of Immigration in a Coordinated National Security Policy." Georgetown Immigration Law Journal 21(5): 383-430.

LIRS (Lutheran Immigration and Refugee Service). 2009. The Real Cost of Welcome: A Financial Analysis of Local Refugee Reception. Baltimore: LIRS.

MGI (McKinsey Global Institute). 2016. People on the Move: Global Migration's Impact and Opportunity. http://www.migration4development.org/sites/default/files/mgi-peopleon-the-move-full-report_1.pdf.

Miliband, David. 2018. "On refugees, the Trump administration is competent and malevolent." Washington Post, April 16.

NAE (New American Economy). 2016. "Welcome to Akron: How Immigrants and Refugees Are Contributing to Akron's Economic Growth." New York: NAE. http://www. newamericaneconomy.org/research/welcome-to-akron/.

- 2017. "From Struggle to Resilience: The Economic Impact of Refugees in America." New York: NAE. https://research.newamericaneconomy.org/report/from-struggle-toresilience-the-economic-impact-of-refugees-in-america/.

NASEM (National Academies of Sciences, Engineering, and Medicine). 2015. The Integration of Immigrants into American Society. Washington, DC: National Academies Press.

Nezer, Melanie. 2014. "An Overview of Pending Asylum and Refugee Legislation in the US Congress." Journal on Migration and Human Security 2(2): 121-43. http://dx.doi. org/10.14240/imhs.v2i2.28.

Nowrasteh, Alex. 2016. "Terrorism and Immigration: A Risk Analysis." Policy Analysis 798. Washington, DC: Cato Institute. https://www.cato.org/publications/policy-analysis/ terrorism-immigration-risk-analysis.

O’Brien, Matthew, and Spencer Raley. 2018. "The Fiscal Cost of Resettling Refugees in the United States." Washington, DC: Federation of American Immigration Reform. https://fairus. org/issue/legal-immigration/fiscal-cost-resettling-refugees-united-states. 
Reagan, Ronald. 1981. "Statement on United States Immigration and Refugee Policy." The American Presidency Project. http://www.presidency.ucsb.edu/ws/?pid=44128.

RPC (Refugee Processing Center). 2018a. “Historical Arrivals Broken Down by Region (1975Present).” http://www.wrapsnet.org/s/Graph-Refugee-Admissions-FY2018_04_30-14jc. xls.

State of Colorado, Office of Economic Security. 2016. "The Refugee Integration Survey and Evaluation: Year Five Final Report." Denver, CO: Colorado Office of Economic Security. https://cbsdenver.files.wordpress.com/2016/03/rise-year-5-report-feb-2016.pdf.

Sturm, Daniel. n.d. "Parishes Organized to Welcome Refugees (POWR): Parish Resources from A to Z." Washington, DC: United States Conference of Catholic Bishops, Migration and Refugee Services. https://c.ymcdn.com/sites/usccb.site-ym.com/resource/collection/ BC82D566-79ED-47AF-A893-879F63587B64/02_MRS_POWR_From_A_to_Z.pdf.

UNHCR (United Nations High Commissioner for Refugees). 2017. Global Trends: Forced Displacement in 2016. Geneva: UNHCR. http://www.unhcr.org/5943e8a34.pdf.

—. 2018a. "Syria Regional Refugee Response." https://data2.unhcr.org/en/situations/ syria\#_ga=2.99337310.152927787.1526410617-763034142.1524054430.

—. 2018b. "Refugees and asylum-seekers from South Sudan." http://data2.unhcr. org/en/situations/southsudan\#_ga=2.99188830.152927787.1526410617763034142.1524054430 .

USCIR (US Commission on Immigration Reform). 1997. "Refugee and Humanitarian Admissions." Washington, DC: USCIR.

US Select Commission on Immigration and Refugee Policy. 1981. "US Immigration Policy and the National Interest: The Final Report and Recommendations of the Select Commission on Immigration and Refugee Policy to the Congress and the President of the United States." Washington, DC: US Government Printing.

World Bank. 2018. "GDP (current US\$)." National Accounts Data. https://data.worldbank.org/ indicator/NY.GDP.MKTP.CD?view=map. 


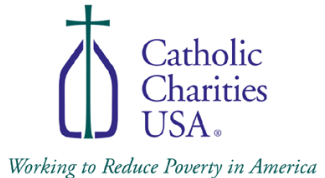

Working to Reduce Poverty in America

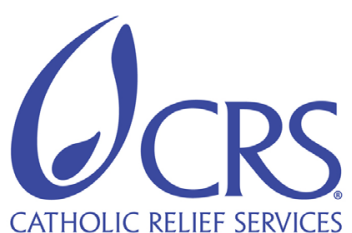

CATHOLIC RELIEF SERVICES

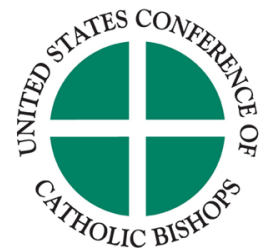

This report was conceived and commissioned by Catholic Charities USA, Catholic Relief Services, and the United States Conference of Catholic Bishops, Migration and Refugee Services.

Donald Kerwin, Executive Director of the Center for Migration Studies (CMS), authored the report. The author would like to thank Robert Warren, CMS Senior Fellow, for providing invaluable advice, assistance, editing, and technical expertise; Mike Nicholson, CMS researcher, for his exhaustive review of the literature on refugee resettlement; and Aimee Chen, CMS Editorial and Production Assistant, for editing and laying out the report. CMS would also like to acknowledge Catholic Charities USA for providing feedback and case studies of refugee entrepreneurs and employers of refugees.

\section{Suggested citation:}

Kerwin, Donald. 2018. The US Refugee Resettlement Program - A Return to First Principles: How Refugees Help to Define, Strengthen, and Revitalize the United States. CMS report, June. New York: Center for Migration Studies. http://cmsny.org/publications/us-refugee-resettlement-program/.

No part of this publication may be reproduced or transmitted in any form by any means, electronic or print, including photocopy, or any information storage retrieval system, without the permission of CMS.

For more information, visit www.cmsny.org.

(C) 2018 Center for Migration Studies of New York (CMS). All rights reserved. 